\title{
An orientation to be a good millennial Muslims: state and the politics of naming in islamizing Java
}

\author{
Askuri \\ Universitas 'Aisyiyah Yogyakarta \\ asykuri@yahoo.com \\ Joel C. Kuipers \\ The George Washington University \\ kuipers@gwu.edu \\ DOI: $10.18326 /$ ijims.v9i1. 31-55
}

\begin{abstract}
Traditionally, Javanese names pretend to be social classifications (priyayi class, santri class, abangan class, lower class, noble class, etc.) and as a marker of time or condition when they were born. In the last 30 years, however, the naming tradition has been increasingly abandoned by a new generation of parents in Java by taking on new names that have never existed in Javanese treasury of names: its linguistic variation is wider and has a future-oriented meaning for their children. Does the shift of meaning in naming have a close connection with Islamization in Java, since this change involves a large number of Arabic names which are one of the Islamic registers in this country? With a naming approach that processed almost one million names from Bantul, this research proves clearly about the indirect role of the state in the growth of Islamic orientation of new generation of parents in Java. They want to connect the future of their children with Islam. Millennial Muslims generation has been indirectly shaped by this new generation of parents through naming, in which
\end{abstract}


the new world that parents want to build for their children is linked to Islam through the Arabic names that have the orientation to become a good Muslim in the millennial era.

Secara tradisional, nama-nama Jawa bisa menjadi penanda klasifikasi sosial (kelas priyayi, kelas santri, kelas abangan, kelas bawah, kelas bangsawan, dan lain-lain), sekaligus sebagai penanda waktu atau kondisi ketika mereka dilahirkan. Namun, dalam 30 tahun terakhir, tradisi penamaan tersebut semakin ditinggalkan oleh generasi baru orang tua di Jawa dengan menggunakan nama-nama baru yang tidak pernah ada dalam perbendaharaan nama Jawa: variasi linguistiknya lebih luas dan memiliki makna berorientasi masa depan. Apakah pergeseran makna dalam penamaan memiliki hubungan yang dekat dengan Islamisasi di Jawa, mengingat perubahan ini melibatkan sejumlah besar nama Arab yang merupakan salah satu register keislaman di negeri ini? Dengan pendekatan penamaan yang memproses hampir sejuta nama penduduk di Kabupaten Bantul, penelitian ini membuktikan dengan jelas tentang peran negara secara tidak langsung dalam pertumbuhan orientasi keislaman generasi baru orangtua di Jawa. Mereka ingin menghubungkan masa depan anak-anak mereka dengan Islam. Generasi Muslim milenial telah secara tidak langsung dibentuk oleh generasi baru orang tua ini melalui penamaan, di mana dunia baru yang mereka inginkan untuk anak-anak mereka terkait dengan Islam melalui nama-nama Arab yang memiliki orientasi untuk menjadi Muslim yang baik di era milenial.

Keywords: Naming; State; Muslims; Javanese

\section{Introduction}

In mid 2015, a man (about 40 years) in Banyuwangi, Indonesia, became viral on social media just because of his name: "Tuhan" (in Bahasa Indonesia means God). Various parties urged him to change his name, including the Chairman of the Indonesian Council of Ulama (MUI) in East Java, KH. Abdusshomad Bukhori, who advised him to change the name or add a word, one that connotes a slave, in front of his name. 
The chairman of Nahdlatul Ulama (NU) also claimed that the name "Tuhan" is not ethically be used by humans. However, this man remained unmoved, as the name is a conferment from his parents that should be accepted and respected.

There is a critical question that needs to be asked: for more than 40 years of his life, no one sued the Banyuwangi man for his name, why, only now do the people question his name on the basis of religious ethics? What actually happened to the people of Indonesia? While at the same time, many scholars view that Indonesia, the biggest Muslim country in the world, is experiencing a resurgence of Islam. ${ }^{1}$ Is the rise of awareness about the meaning of the name have a close relationship with the rise of Islamic piety in Indonesia? On the other hand, Arabic names that have been identified as Islamic names are also growing rapidly in the same time. Does the growth of Arabic names in Java have a correlation with the rise of Islam in this country? This article will give a comprehensive explanation of the dynamics of the Arabic names in Java, the biggest ethnolinguistic group in Indonesia, and its relationship with Islamisation in this country.

In contrast to William Shakespeare, the Javanese positioned the name as something very meaningful. Thus, the name of the Javanese contains a wider social dimension, and can be used to interpret social dynamics in Java. Therefore, this research uses a naming approach to see Islamization in Java. With statistical narratives sharpened by ethnography, this research will explain the growth of Islamic orientation of millenial generation in Java. I took data from Bantul, an area that was once assumed to be a base of abangan. ${ }^{2}$

\footnotetext{
${ }^{1}$ Robert Hefner, Islam Pasar Keadilan: Artikulasi Lokal, Kapitalisme, dan Demokrasi, Yogyakarta: LKIS, 2000.

${ }^{2}$ Clifford Geertz, The Religion of Java, New York: Free, 1960. See also: Koentjaraningrat, Kebudayaan Jawa, Jakarta: Balai Pustaka, 1994.
} 


\section{The statistics of naming: a new approach of Islam in Java}

Statistically, millennials in Java share the same identity: leaving the naming tradition in Java and adopting new names that have never existed in the name treasury in Java. The typical Javanese names used by previous generations are increasingly lost from the millenial generation treasury in Java.

Figure 1. The Dynamics of Naming in Bantul

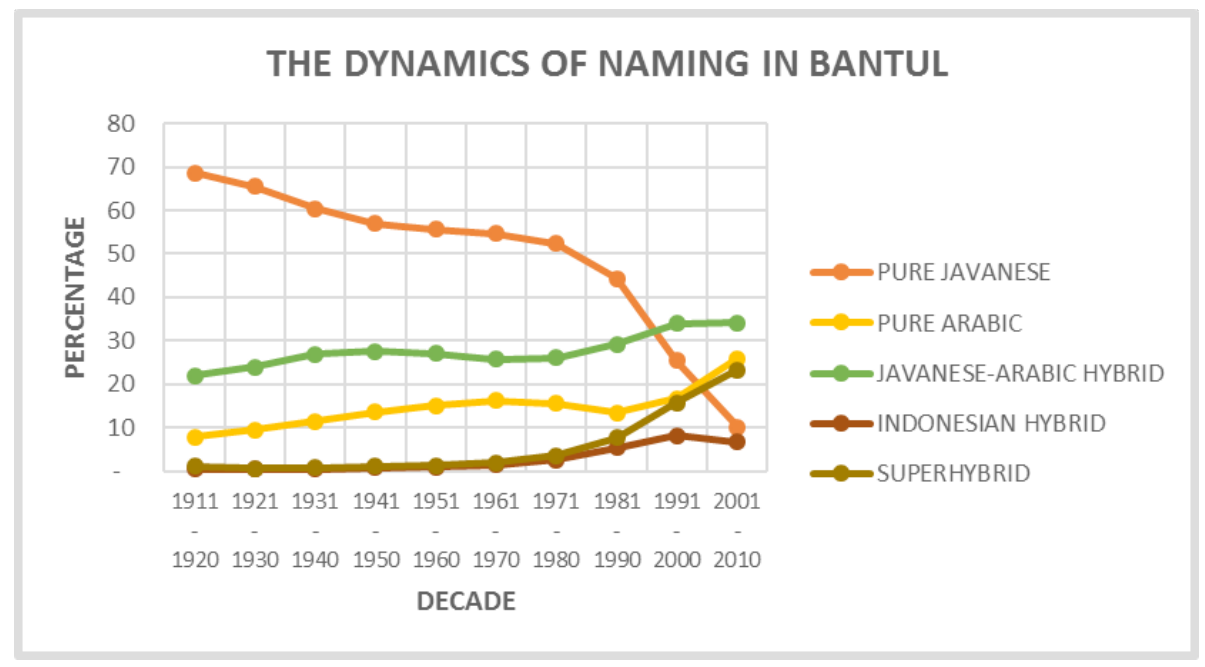

From the statistical description above, between the years 1911-1980, the pure Javanese names ranked highest in Bantul (every decade over $50 \%$ of the population use it). This could justify that Bantul was one of the home of kejawen in the past. However, since the transition of $1980 \mathrm{~s}$ to 1990s, the pure Javanese names drop drastically in this region, and approaching its nadir at the ten percent level at the beginning of the 21st century. Pure Arabic names crept up to twenty-six percent at the same period. At the same time, Javanese-Arabic hybrid names also crept up 
to thirty-four percent. Meanwhile, Indonesian hybrid and superhybrid names, which until the 1970s were not used by many Javanese people, experienced a growth in the late 1980s. Specifically, superhybrid names have grown sharply until the beginning of the 21 st century.

The statistical descriptions above confirm a conclusion: in the transition from the 1980s to the 1990s, there was a dramatic change in Javanese naming, where pure Javanese names decline dramatically, while at the same time, Arabic names and hybrid names (Javanese-Arabic hybrid, Indonesian hybrid, and superhybrid) have increased. Among the categories of names that are increasing dramatically are superhybrid names, which hybrid names consist of three or more languages, especially Javanese-Arabic-European names. What caused a dramatic change of naming in Java? Some of the following anthropological descriptions may possibly open up hidden social narratives in the dynamics of Javanese identity.

\section{The anthropology of naming in Java}

In the past, Javanese communities are classified into 3 sub-cultures: Santri, Abangan, and Priyayi. ${ }^{3}$ The social classification is also reflected in Javanese naming. The Abangan families usually give suitable names of Javanese days for their children (like Senen or Pahing), or simple names, such as Sidin or Sirin. The Priyayi families usually give name Bambang or Joko with any other additional names for their sons, while the Santri families usually give Arabic names for their babies, like Muhammad, Abdul, or Siti with any other additional names. ${ }^{4}$

The peasant families usually give short names to their newborns, which often refers to the birth of the baby, such as: Ponimin, Ponijan, Poniyah,

\footnotetext{
${ }^{3}$ Clifford Geertz, The Religion of Java...

${ }^{4}$ Clifford Geertz, The Religion of Java..., 47-48.
} 
and Poniyem (which refers to Javanese day: Pon); Legimin, Legino, Legiyah, and Legiyem (which refers to Javanese day: Legi), or Wagiran, Wagino, Waginah, or Wagiyah (which refers to Javanese day: Wage). In addition, the peasant families often give names that have simple meanings to their children, such as Bejo, Slamet, Untung, and so forth. ${ }^{5}$ In the higher class, many names are taken from the stories of Javanese wayang or literature, such as Sukarno, Suhadi, Sri Sumarah, Lestari, or Kartini, while the lower class of Santri often adopt names from Arabic, such as Durrahman, Alip, Kusin, Aminah, etc. ${ }^{6}$

In the past, most Javanese people generally did not practice naming ceremonies. Most families give a name to a newborn baby when he or she was born, which is accompanied by a ceremony of slametan or brokohan. The ceremony is only meant to celebrate the birth of a baby, not a naming ceremony, because the name is given automatically. ${ }^{7}$ The Santri families hold a naming ceremony on the seventh day after the birth with a ceremony of aqiqah or "kekah" (according to Javanese tongue), accompanied by a slaughter of goat (one goat for a girl, or two goats for a boy) to be cooked and distributed to neighbors. ${ }^{8}$

Javanese parents also know which names to give their children, according to social class. A peasant, for example, would not be given a name that ends with -kusuma, -tanaya, or -ningrat. These names are only fitting for the Javanese priyayi. A peasant would not feel comfortable giving these names to their children, not only because of being ridiculed by their entire village, but also because there is a belief that such a name would bring bad luck to their children, because it is "too heavy" for them

${ }^{5}$ Ron Hatley, What's in a name: Arti Sosial seperti Terlihat dalam Nama dan Perubahan Laziman (Mode) Nama di Jawa, Yogyakarta: Universitas Gadjah Mada, 1977.

${ }^{6}$ Moordiati, "Saat Orang Jawa Memberi Nama: Studi Nama di Tahun 1950-2000", Patrawidya, volume 16, number 3 (September 2015), 381-390.

${ }^{7}$ Koentjaraningrat, Kebudayaan Jawa...

${ }^{8}$ Moordiati, "Saat Orang Jawa..." 
(in Javanese called "kaboten jeneng"). ${ }^{9}$ As Uhlenbeck has stated, the names which are considered eligible for the lower classes (peasant) are usually simple names with suffix “-em” or “-en” for women, or “-an”, “-in”, or “-un” for men. ${ }^{10}$

One of the prevailing ways of naming children in Java also include a layer of global civilization that once flourished in Java: Sanskrit; Arabic/ Islam; and Western. Many Javanese have names that feels "Sanskritized," while many of them also have Arabic names or "Arabized" names. Some names are also "Persianized," but are still categorized as Arabic names. Many names have also adopted western names, or "westernized" names. The "foreign names" used in Java can also be associated with many layers of Indonesian history. Hinduism and Buddhism has now become a part of Indonesian culture, as well as Sanskrit. Islam came to Java in the 15th century (or even earlier), and has become a part of Indonesian culture, including Arabic literature and names. Western colonialism once colonized this country for hundreds of years, and still persists in the form of globalization today.

Javanese people are easily recognizable from their names. Their names seem simple, with only one syllable or two syllables, with the suffix "o" for men, and the suffix " $i$ " for women. ${ }^{11}$ The children are always called by the father's nickname, which often change throughout his childhood. The childhood names are simply temporary names. When the boy becomes a man, however, a new name becomes important. Therefore, the new naming ceremony for boys who have become adults is an important event, ${ }^{12}$ and is usually held to coincide with the time of marriage. This

\footnotetext{
${ }^{9}$ Carel Poensen, "Lets over Javaansche Naamgeving en Eigennamen", in Mededeelingen Vanwege het Nederlandsche Zendeling Genootschap XIV, Rotterdam: M. WYT \& Zonen, 1870.

${ }^{10}$ Eugenius Uhlenbeck, Systematic Features of Javanese Personal Names, in: A. Juilland, ed. New York: International Linguistics Assn., 1971, 321-335.

${ }^{11}$ Eugenius Uhlenbeck, Systematic Features... See also: Moordiati, "Saat Orang Jawa..."

${ }^{12}$ Koentjaraningrat, Kebudayaan Jawa...
} 
adulthood name applies only to man, because the woman usually uses her husband's name.13

Although there are scholars who have examined Javanese names, many of them do not reveal the state's role in the naming of their people. Although Uhlenbeck ${ }^{14}$ has conducted research on name changes in Java, he did not direct his analysis on the influence of ID cards and birth certificates (issued by the state) in naming. With identity cards showing residency, officially recognized by the state, the opportunity to change the name in the Javanese tradition (from childhood names to adulthood names) becomes difficult, due to the fact that the renaming process involves complicated court procedures, and implicates the change of all official documents, such as diplomas, bank accounts, driver's license (SIM), and so forth. With such a complicated procedure, people are reluctant to take care of the name change, so the baby's name is usually defined beginning at birth.

Because of the name has been defined with certainty since the birth of the baby, the naming can no longer be given simply, as childhood names were given in the past. Children naming processes for the Javanese now exclude Javanese traditional names. They involve using more modern names which are more pleasing to the ear. ${ }^{15}$ Some scholars say that Javanese contemporary naming increasingly avoids negative connotations: e.g. lower classes or ignominious epithet, ${ }^{16}$ or bad and stupid names with a view to warding off the bad influence of evil spirits. One of the important changes in the practice of naming in Java is that the contemporary Javanese community tries to choose a name that connotes a good, positive, and modern image for their children.

${ }^{13}$ Eugenius Uhlenbeck, Systematic Features...

${ }^{14}$ Eugenius Uhlenbeck, Systematic Features...

${ }^{15}$ Moordiati, "Saat Orang Jawa..."

${ }^{16}$ Djatmika, "Pemberian Nama Panggilan dalam Masyarakat Jawa: Sebuah Studi Kasus di Surakarta", a paper in Kongres Internasional Masyarakat Linguistik Indonesia (KIMLI), Surakarta: Universitas Sebelas Maret Surakarta, 2011. 


\section{Islamic literacy, religious standardization, and the choice of Arabic names}

In response to the 1965 national tragedy (G30S/PKI), the Provisional People's Consultative Assembly (MPRS) imposed a decree (TAP MPRS No. XXVII/MPRS/1966) to enforce religious education obligations at all levels of education in Indonesia. Since then, religious education has become mandatory at all levels of schools and colleges. It was a turning point for Islamic religious education, having for so long never gained a structural place in state-run schools. Before the adoption of the MPRS Decree, Islamic religious education was only optional in public schools. In fact, in many schools in rural Java, Islamic education was rendered gratuitously by Abangan teachers who had no knowledge of normative Islam. ${ }^{17}$ However, since the adoption of the MPRS Decree of 1966, religious education has become mandatory for all students at all levels of education, without any reason to object or to reject it.

The State implements this policy by optimizing the graduates of Religious Teacher Education (PGA) to teach Islamic Religious Education in public and private schools, including in rural schools that form the basis of the Abangan. In the midst of the post-1965 tragedy, many Abangan teachers affiliated with the PKI had become victims of the massacres. Islamic education taught by Abangan teachers would be counterproductive, as this would only provoke the reaction of the Muslims who had just won an ideological battle against communism. Anyone that went against Islam or mocked Islam would be accused of being affiliated with the PKI, and risk being slaughtered. Therefore, the Abangans who had so far become supporters of the PKI chose safety by accepting any state policy, including accepting the Islamic teachers placed by the state in the schools of their village.

\footnotetext{
${ }^{17}$ Robert Hefner, Islam Pasar Keadilan...
} 
Islamic religious teachers which were stationed in Abangan villages present different Islamic teachings from the Abanganese Islamic tradition. Although the Abangan are Muslims, there are many Islamic practices they do not practice: they do not perform prayers, fasting, zakat, or pilgrims, and cannot read the Quran. They actually practice the ancient beliefs of Kejawen that are substantively contrary to the teachings of Islam. Through Islamic religious education conducted 2 hours a week at school by "competent" teachers of Islam, Abangan children learned about normative Islam, unlike their parents and family. They were taught about monotheism, shirk, and Islamic rituals, such as prayer, ablution, washing, zakat, fasting, and others.

"What makes me surprised at the first time when was taught by Pak Ramlan (a religious teacher) is that the offering for the dead is a shirk. At first, I opposed the teaching in my heart, but after I thought, uh right, it is impossible that Gusti Allah is given the food offerings". ${ }^{18}$

Quranic literacy is one of the teachings of Islam in schools. It is difficult, but challenging. They are very excited about the reward of 10 goodness by reading one letter of the Quran, although they find it difficult to read it, especially distinguishing some sounds that are almost similar. In Arabic phonology, there are almost identical sounds, such as the sounds of $/ s /, / s y /$, and $/ s h /$. However, the sounds were challenging for the Abangan children. Not all of the children were finally able to read the Quran, but the heavenly sounds stimulated a more normative Islamic orientation of piety. Many of them later requested additional hours with Islamic religious teachers to teach Quranic literacy in the afternoon or evening.

"I can read the Quran when I was in the second grade of junior high school. At that time there was no mosque in my village. There is a mosque, but it

\footnotetext{
${ }^{18}$ Interview with Ngadiyo, a peasant, 54 years old, in Bantul.
} 
was far away. In the mid1970-s there was a religious teacher who lived in my neighbor's house. I like him when he taught religion teaching, because he is funny. He explained many things about Islam. Although I am Muslim from birth, I did not understand many things. He taught me from the bottom. Also, he taught Quranic literacy after maghrib. I remember when he was teaching the Quran. Distinguishing some almost identical sounds is interesting. At that time, he said that reading Quran must be fluent (fasih), because if it is not fluent, it can change the meaning of the Quran. That's what I hold firmly until now". ${ }^{19}$

What these witnesses have said is similar to how Gade describes the growth atmosphere of Quranic learning 30 years later, ${ }^{20}$ though not as massive as in the 1990s when Gade conducted research in Indonesia. As the Qur'anic recitations are brought to the children, some of them experience an "interesting pull" they may not have guessed, where this engagement brings a broader motivation and results in an increased sense of religiosity. With the correct reading technique (makhraj al-huruf and tajwid), Qur'anic learning produces a new level of self-understanding and inspiration that becomes the students' own motivation.

The teachings of Islam and the Quranic literacy at the schools seemed to foster a new awareness in children that there was something different from what they understood and experienced within the family: the Islamic teachings they have learned from their family are wrong. The next awareness that grows is a new orientation towards Islamic piety that is more normative, in contrast to the Islamic tradition of Kejawen that takes place in their families.

"The religious lesson was very impressive, although only limited. Nevertheless, it provided the basis for my own development. In 1970s it has started there were Islamic recitation. There are many kyai coming to the village. Many people came to follow his lecture. I am often invited by my father participated

\footnotetext{
${ }^{19}$ Interview with Gito Wiyono, a merchant, 56 years old, in Bantul.

${ }^{20}$ Anna Gade, Perfection Makes Practice: Learning, Emotion, and the Recited Qur'an in Indonesia, Honolulu: University of Hawaii Press, 2004.
} 
in the lecture. I also paid attention to what the lecturers are saying. I thought there was something wrong with the beliefs of old people. Why were Muslims not praying, not fasting, not zakat? Even though it is clearly commanded in the Quran". ${ }^{21}$

The new orientation towards a more normative Islamic piety did not stop at school. The call of Islamic piety always attracts them to continue to study and seek more normative Islamic teaching. Amid the growing spirit of normative Islamic learning, the dakwah movement was more intensively implemented. When students entered college, they were greeted by the Campus Dakwah Movement, which has mushroomed since the 1980 s. $^{22}$

"I did not think that UGM campus which is a public university turned out to be a lot of Islamic activities. In the early 1990s Ramadlan's activities in Campus were remarkable. The whole campus was suddenly Islamic. As a plebeian child, I feel that here is where I can learn modern Islam, there are many lecturers who are prominent Muslim intellectuals, such as Amien Rais. Unlike Islam in our kejawen village". ${ }^{23}$

Children of Abangan parents in the post-G30S/PKI generation affects the names of their children when they become a new generation of parents after marriage: they tend to choose Arabic names. The choice of Arabic names indicates that they want to connect their children's future with Islam.

"Sure, I chose the Arabic name. I assembled it myself: Muhammad Fauzan Akbar. It means good, commendable with great victory. I want my son to be on the path of Islam. So, any later, he must remain in Islam". ${ }^{24}$

${ }^{21}$ Interview with Sudiyono, a peasant, 58 years old, in Bantul.

22 Elizabeth Collins, "Islam and the Habits of Democracy", Indonesia, Volume 78, (2004), 93-120. See also: Richard Kraince, The Role of Islamic Student Activists in Divergent Movements for Reform during Indonesia's Transition from Authoritarian Rule, 1998-2001, Ohio: Ohio University, 2003.

${ }^{23}$ Interview with Purnomo, a private employee, 47 years old, in Bantul.

${ }^{24}$ Interview with Mugiyanta, a teacher, 41 years old, in Bantul. 
However, the Arabic names they use to name their children are no longer the same as the previous generation. The Arabic names of earlier generations tend to use domesticated Arabic names, while the Arabic names used by the new generation of parents tend to use pure Arabic names, globalized Arabic names, and Arabic names in combination with other linguistic elements. In general, they want to show a new achievement in Islamic piety: more (Quranic) literate, and in some ways more cosmopolitan.

"The names of the children are in accordance with the times. Certainly, it also must fit the existing developments, including Arabic names. Nowadays, writing Arabic name that if careless will be laughed by people. If it is written like old people used to be old-fashioned. There is a standardization of Arabic writing in Latin script. Automatically, the Arabic names must also comply with that standard". 25

In the context of naming, the Arabic names which have been given to children born since the 1980s have been purified, using standardized Arabic-Indonesian transliteration. Therefore, some errors in the transliteration of the names in official state documents (such as ID cards) can no longer be altered, and thus cause feelings of discomfort to the bearers of those cards, because they make them appear to be Quranically illiterate.

"A few years ago, one of my students came to the house. In particular, he thanked me for suggesting renamed. His real name is Parjiman. He used to be very clever, although coming from a mediocre family. As a religious teacher, I regret the name, it means dirty. I suggested he change the name, while there was a massive accomplishment of birth certificate. His parents agreed. Thus, in his birth certificate a new name was written: Fajri Ahmad. Apparently, he is now an official in the Ministry of Religious Affairs". ${ }^{26}$

In the midst of a wave of Islamic resurgence in Indonesia, purification

\footnotetext{
${ }^{25}$ Interview with Imam Muhsin, a lecturer, 44 years old, in Bantul.

${ }^{26}$ Interview with Konitun, a retired teacher, 65 years, in Bantul.
} 
is an integral aspect. Today, everything that contains traditions is questioned and sued for its religious basis. If that tradition does not come from the Prophet it can be called heresy, including all deeds that have no syar'i proof from the time of the Prophet. ${ }^{27}$ Moreover, all the latest things that have nothing in relation to religious contexts tend to be Islamized, ${ }^{28}$ such as Islamic cosmetics, sharia hotel, and so on.

The Islamic education that was introduced and made mandatory by the state since the early 1970s has led the Abangan children to have some kind of communicative competence ${ }^{29}$ in Islamic literacy. Now they have grown into a new generation of parents in young families. With a communicative competence in Islamic literature that is more developed than previous generations of parents, they choose Arabic names for their children. However, their choice of Arabic names which tend to be purified (as a sign of the Quranic literate) and globalized (as a sign of cosmopolitanism) indicates that they want to be different from the Arabic names of earlier Muslim generations, which tend to be domesticated (which is a marker of Quranic illiterate). Like the politics of onomastics, ${ }^{30}$ the responsibility of the new generation of parents in naming their children is one of their forms of narcissism to be recognized in a new generation of Muslims. Some of them chose the standardized Arabic names as an implementation of the religious teachings they have learned, especially choosing a good name for their children as a prayer and hope for their future. As a prayer, the Arabic names must conform to

27 Imam Al-Syatibi, Al-I'tishom: Buku Induk Pembahasan Bid'ah dan Sunnah, Jakarta: Pustaka Azzam, 2006.

${ }^{28}$ Alina Kokoschka, "Islamizing the Market? Advertising, Products, and Consumption in an Islamic Framework in Syria”, in Muslim Societies in the Age of Mass Consumption, Newcastle upon Tyne: Cambridge Scholars, 2009, 225-240.

${ }^{29}$ Dell Hymes, "On Communicative Competence", in Sociolinguistics, London: Penguin Books Ltd., 1972.

30 Jacques Derrida, "Signature Event Context", in Margins of Philosophy, New York: Harvester Wheatsheaf, 1982. 
the right transliteration standard, so as not to alter its intended meaning.

\section{Higher education, urbanization, and the choice of Arabic names}

The beginning of the New Order era is known as the era of development, which benefitted from oil boom. The rising global oil prices pushed Indonesia to export oil to fund development. One form of development was the development of education in the New Order with the program of SD Inpres in the academic year 1973/1974. ${ }^{31}$ The program expanded access to education by building schools up to the village level as a form of support for compulsory education programs (program wajib belajar) in 1984. This policy had an impact on increasing the number of primary school children each year and the building of more elementary school buildings.

For the village community in Java at that time, the policy made access to basic education easier and closer. Previously, although Law Number 4 Year 1950 has set a 6-years compulsory education program, access to basic education in rural Java was uneven. There were many villages that did not have school buildings, so their children were forced to travel between villages every morning to study at school. They were unsupported by inadequate road facilities, including muddy roads when it rained. Laborless peasant families preferred to sacrifice their children's education to work in the fields or to seek grass for their livestock.

The presence of school buildings (SD) in almost every village in Java was accompanied by the enforcement of the previous policy on Compulsory Education of 6 years. The socialization of the 6-year Compulsory Education policy had a tremendous impact on the awareness of peasant families in rural Java about the importance of education for

\footnotetext{
${ }^{31}$ Revrisond Baswir, Dilema Kapitalisme Perkoncoan, Yogyakarta: Institute of Development and Economic Analysis dan Pustaka Pelajar, 1999, 116.
} 
their children. They feel that by going to school their children will be smarter, unlike themselves: illiterate and only able to work in the fields. The village heads are actively involved in encouraging citizens to send their children to school. The village head even went to the children in his village who were reluctant to leave for school.

"I remember in the late 1970s, my father bought me two goats, one male and one female. He said it was for school preparation after I graduated from elementary school. After 3 years, the goats are already breeding. When I entered junior high school, some of them were sold to buy me a bike that I used to go to school. That was the first time happened in my family. My two sisters only graduated from elementary school, while I graduated high school. For college, I seek my own cost". ${ }^{32}$

Some of the children in rural Java who studied at SD Inpres did not realize that their presence on the school bench was the starting point of their uprootment from their cultural roots in agriculture. A dozen years later they grew into an educated workforce, graduated from various universities, and were ready to work in various sectors outside of agriculture and away from their farm-based homes. They do urbanization. In this urbanization, they met their different spouses (even from outside Java). They grew into new families. The growth of new families has caused their attachment to each tradition to become loose. In naming children, they no longer rely on the tradition of asking elders or kyais for names. They rely on the latest sources in naming their children: books, magazines, and the internet.

In addition, couples who are far away from this hometown eventually have to compromise on behalf of their children. They usually choose Arabic names as a sign of hope and prayer for their children's piety, although it is combined with other linguistic resources.

"As a Javanese-Minang couple, we agreed not to name a child with a Javanese or Minang name. The choice is Arabic name, because it can accommodate our

\footnotetext{
${ }^{32}$ Interview with Siraji Munir, a teacher, 47 years old, in Bantul.
} 
expectations both about the future of children, especially pious children". ${ }^{33}$

In some respects, Arabic names represent a compromise of naming between husbands and wives of different backgrounds. The wives in these new families benefitted from the New Order's successful education policy of providing primary education, and dramatically increased the participation of women in secondary education and higher education. ${ }^{34}$ Although female enrollment still lags behind male students, the gap continues to narrow. In 1971, the balance between men and women in college was $48 \%$, but in 1990, the gap narrowed to $29 \% .{ }^{35}$ In 2009/2010, the gap was almost nonexistent, leaving only $0.12 \% .{ }^{36}$

\section{State and Islamization: an interpretation from the growth of Arabic naming}

By tracing the history of change in the Muslims of Java, especially postG30S/PKI tragedy, the celebration of meaning in naming their children will be understood from a historical context, which this is not separated from the influence of the state. First, Muslims experienced a growth in education and literacy, which has been very significant since Indonesia's independence. With the program of literacy education at the beginning of Sukarno's government, the literacy rate of Indonesian people rose to forty percent in the 1960s. In the 1990s, when the New Order government was still in power, the literacy rate rose sharply to ninety percent. ${ }^{37}$ The report

\footnotetext{
${ }^{33}$ Interview with Aslamawati Choirun Nisa, an employee, 42 years, in Bantul.

34 Gavin Jones, Marriage and Divorce in Islamic South-East Asia, New York: Oxford University Press, 1994. See also: Oey-Gardiner, "Gender Differences in Schooling in Indonesia”, Bulletin of Indonesian Economic Studies, Volume 27 (1991), 57-79.

${ }^{35}$ Terence Hull, \& Gavin Jones, "Demographic Perspectives”, in Indonesia's New Order, Hawai: University of Hawaii Press, 1994.

${ }^{36}$ Kementerian Pendidikan dan Kebudayaan RI, Perkembangan Pendidikan Tinggi Tahun 199/2000 - 2013/2014. Buku 1 ed. Jakarta: Kementerian Pendidikan dan Kebudayaan RI, 2015.

${ }^{37}$ Gavin Jones \& Chris Manning, "Labour Force and Employment during the 1980s", in
} 
by the Central Statistics Agency (BPS) in 2014 states that the literacy rate of the Indonesian population, aged $15-24$, increased by $99.68 \%$, while the literacy rate of the population, aged 15-59 years, increased by $97.17 \%,{ }^{38}$ In addition, the percentage of people who finished high school increased dramatically, from approximately four percent in 1970, to over thirty percent in the 1990s. ${ }^{39}$

Assuming that the majority of the population in this country is Muslim, the most widely benefitted from these literacy programs are Muslims. With literacy skills, they can broaden their horizons of thought through readings, access a variety of information through media, and actualize ideas through writing. Almost similar to the effect of print capitalism against European nationalism, ${ }^{40}$ Muslim literacy can be held in conjunction with the expansion of higher education, and the rise of a market for Islamic books and newspapers. ${ }^{41}$ This encourages "the objectification of Islamic knowledge", where Islam becomes an object of interest from a number of people who are increasing in number. ${ }^{42}$

Secondly, the deterioration of the nominal Muslims (Abangan) in Java post-G30S/1965. Prior to the national tragedy, religious education in schools was optional. However, after the victory of the army, along with Muslims and other religions, extinguishing the PKI was considered necessary as they were considered the responsible party for the tragedy. MPRS, as the highest state institution, established TAP MPRS No. XXVII/

The Oil Boom and After: Indonesian Economic Policy and Performance in the Soeharto Era, Oxford: Oxford University Press, 1992, 399.

${ }^{38}$ Badan Pusat Statistik, Statistik Pendidikan, Jakarta: Badan Pusat Statistik, 2014.

${ }^{39}$ Terence Hull, \& Gavin Jones, “Demographic Perspectives”..., 162.

${ }^{40}$ Bennedict Anderson, Imagined Communities: Reflections on the Origin and Spread of Nationalism. Brooklyn: Verso, 2006.

${ }^{41}$ George Atiyeh, The Book in the Islamic World: The Written Word and Communication in the Middle East, New York: State University of New York Press, 1995.

${ }^{42}$ Dale Eickelman \& J. Piscatori, Muslim Politics, Princeton: Princeton University Press, 1996. 
MPRS/1966, which requires all schools at all levels to organize religious education for students. As a result of this policy, Islamic education became compulsory. Teachers of Islamic education in schools joined the Religious Teacher Education (PGA), a school which was established by the government. The graduates of this school can easily secure jobs as teachers of Islamic education. They can be placed throughout Indonesia. As a result of this policy change, the children of nominal Muslims (the Abangan), previously unable to receive Islamic education that was appropriate with the Islamic orthodoxy standard, received normative Islamic education amongst the Santri.

Although there are few accurate statistics, this focus on broad religious education, more or less, influenced the religious understanding of Abangan children. The religious education encouraged the growth of a large wave of "childhood curiosity" in Islam that increasingly facilitated events outside of the religious learning in schools, either intra- or extra-schools/colleges. As a result, their religious understanding became more normative, in accordance with the prevailing Islamic orthodoxy among Santri. It is contrary to the religious understanding of their parents, who were less orthodox.

Indonesian observers have long suspected that the Abangan in Java have experienced a sharp deterioration. ${ }^{43}$ Obviously, this decline is not only due to Islamic learning in schools for two hours a week. However, it actually quite effective in attracting young people from the Abangan to learn Islam. There must be other reasons contributing to the deterioration of the Abangan in Java.

When the New Order was in power, the presence of the state became stronger. As a result, local traditions became increasingly weak. In this context, for many people in Indonesia, Islam was seen as a safe alternative in

\footnotetext{
${ }^{43}$ Robert Hefner, Islam Pasar Keadilan... See also: M. Ricklefs, Islamisation and Its Opponents in Java: A Political, Social, Cultural and Religious History, C. 1930 to the Present, Honolulu: University of Hawai'i Press, 2012.
} 
a political structure that was seen as very strict. ${ }^{44}$ Despite the rise of Islam in Indonesia accounting for the fragmentation of religious authority, ${ }^{45}$ as seen in many other Muslim countries, the religious atmosphere in Indonesia showed standard characteristics. The state policy only recognizes five official religions (Islam, Protestantism, Catholicism, Hinduism, and Buddhism) as a valid option for citizens. The New Order effectively attempted to erase the original religions practiced within local communities. The anthropologists who worked in these areas in the 1970s and 1980s provide clear reports about the damaging impact of the policy on original religions; these policies encouraged conversion to Christianity or Islam. ${ }^{46}$

Disappointed with the participation of Muslim organizations in the anti-communist massacres in 1965-1966, ${ }^{47}$ a number of kejawen people - perhaps five percent of the Javanese people - practiced Hinduism or Christianity in the early years of the New Order, ${ }^{48}$ while others sought

\footnotetext{
${ }^{44}$ Adam Schwars, A Nation in Waiting: Indonesia in the 1990s, Boulder: Westview, 1994.

${ }^{45}$ Dale Eickelman \& J. Piscatori, Muslim Politics...

${ }^{46}$ Joel Kuipers, Language, Identity and Marginality in Indonesia: The Changing Nature of Ritual Speech on the Island of Sumba, Cambridge: Cambridge University Press, 1998. See also: L. Aragon, Divine Justice: Cosmology, Ritual and Protestant Mission in Central Sulawesi, Indonesia. University of Illinois, Urbana: UMI, 1992; J. Atkinson, "Religions in Dialogue: The Construction of an Indonesian Minority Religion”, American Ethnologist, Volume 10 (1983), 684-696; J. Hoskins, "Entering the Bitter House: Spirit Worship and Conversion in West Sumba", in Indonesian Religions in Transition, Tucson: University of Arizona Press, 1987; R. Kipp, Dissociated Identities: Ethnicity, Religion, and Class in an Indonesian Society, Ann Arbor: University of Michigan Press, 1993; M. Rossler, "Islamization and the Reshaping of Identities in Rural South Sulawesi", in Islam in an Era of Nation-States: Politics and Religious Renewal in Muslim Southeast Asia, Honolulu, HI: University of Hawaii Press, 1997, 275-306; P. Spyer, "Diversity with a Difference: Adat and the New Order in Aru (Eastern Indonesia)", Cultural Anthropology, Volume 11 (1996), 25-50.

47 Robert Cribb, The Indonesian Killings: Studies from Java and Bali, Clayton Victoria Australia: Center for Southeast Asian Studies Monash University, 1990. See also: Robert Hefner, The Political Economy of Mountain Java: an Interpretive History, Berkeley: University of California Press, 1990.

48 Hyung-Jun Kim, Reformist Muslims in a Yogyakarta Village, Canberra: Department of Anthropology Australian National University, 1996. See also: M. Lyon, Politics and Religious Identity: Genesis of a Javanese-Hindu Movement in Rural Central Java, Berkeley: Department of Anthropology University of California, 1977.
} 
protection under the umbrella of "Aliran Kepercayaan". ${ }^{49}$ However, both of these developments were limited by the increasing number of kejawen people who carried out more conventional Islamic faiths. ${ }^{50}$

Third, the role of civil Islam in civil participation space creates a new moral framework for the community, in the face of a rapidly changing world. The changes in consumerism, communication, education and post1966 politics undermine local-based hierarchies and values. ${ }^{51}$ Even those villagers that are in the corners of the archipelago were introduced with the goods, fashion and political ideas that were disseminated nationally. With an increase in the presence of the state, and of restrictions on the political structure in the 1950s, the party-based role also weakened the structure of patronage, local prestige, and cultural identity that had once belonged. The change made local elites invest their resources, rather than their local relationships, on consumer goods, education, and the capital that is capable of functioning as a currency in the market of this country. Almost all regions in this country became more accommodative. The lifestyle and local traditions have become more Indonesian.

\section{Conclusion}

By considering several field data tested through a series of discussions with relevant theories, there are several conclusions that can be taken in this article. First, a large number of people names which are analyzed statistically and contextualized with a number of perspectives can be a reliable approach to broader social analysis. In this context, the growth

\footnotetext{
${ }^{49}$ Sven Cederroth, Survival and Profit in Rural Java...

50 Robert Hefner, "The Political Economy..., 53-78. See also: M. Pranowo, Creating Islamic Tradition in Rural Java, Melbourne: Department of Anthropology and Sociology Monash University, 1991; H.J. Kim, Reformist Muslims...

${ }^{51}$ John Bowen, Muslims Through Discourse: Religion and Ritual in Gayo Society, Princeton, NJ: Princeton University Press, 1993. See also: R. Kipp, Dissociated Identities: Ethnicity, Religion, and Class in an Indonesian Society, Ann Arbor: University of Michigan Press, 1993.
} 
of Arabic names in Java since the late 1980s could direct the analysis of Islamization (the growth of the orientation of Islamic piety) among Javanese people.

Secondly, by using naming that developed in society as an approach, we can also identify what is the role of the state in Islamization in Java. Although naming is the free will of every individual in this country, political change at the state level has a major influence on the tradition of naming in society. The state initiation in literacy and education has benefited the Muslims who are the majority in this country. They succeeded in accumulating social capital through education which eventually led them to experience vertical mobility. In the midst of the political narrative of Islam that is supported by the state, including religious education, the Islamic ummah also narrates its hopes about the future of their children to connect with Islamic piety through Islamic naming with more modern linguistic variations.

\section{Bibliography}

Al-Syatibi, I., Al-I'tishom: Buku Induk Pembahasan Bid'ah dan Sunnah. Jakarta: Pustaka Azzam, 2006.

Anderson, B., Imagined Communities: Reflections on the Origin and Spread of Nationalism. Brooklyn: Verso, 2006.

Aragon, L., Divine Justice: Cosmology, Ritual and Protestant Mission in Central

Sulawesi, Indonesia. University of Illinois, Urbana: UMI, 1992.

Atiyeh, G.N., The Book in the Islamic World: The Written Word and Communication in the Middle East. New York: State University of New York Press, 1995.

Atkinson, J.M., "Religions in Dialogue: The Construction of an Indonesian Minority Religion”, American Ethnologist, Volume 10, Issue 4 (1983): 684-696.

Badan Pusat Statistik. Statistik Pendidikan. Jakarta: Badan Pusat Statistik, 2014.

Baswir, R. Dilema Kapitalisme Perkoncoan. Yogyakarta: Institute of 
Development and Economic Analysis dan Pustaka Pelajar, 1999. Bowen, J.R., Muslims Through Discourse: Religion and Ritual in Gayo Society. Princeton, NJ: Princeton University Press, 1993.

Cederroth, S., Survival and Profit in Rural Java: The Case of an East Javanese Village. Richmond, Surrey: Curzon Press, 1995.

Collins, E.F., "Islam and the Habits of Democracy", Indonesia, Volume 78 (2004): 93-120.

Cribb, R. The Indonesian Killings: Studies from Java and Bali. Clayton

Victoria. Australia: Center for Southeast Asian Studies Monash University, 1990.

Derrida, J., "Signature Event Context", in Margins of Philosophy. New York: Harvester Wheatsheaf, 1982.

Djatmika, "Pemberian Nama Panggilan dalam Masyarakat Jawa: Sebuah Studi Kasus di Surakarta”, a paper in Kongres Internasional Masyarakat Linguistik Indonesia (KIMLI), Surakarta: Universitas Sebelas Maret Surakarta, 2011.

Eickelman, D.F. \& Piscatori, J. Muslim Politics. Princeton: Princeton University Press, 1996.

Gade, A.M. Perfection Makes Practice: Learning, Emotion, and the Recited Qur'an in Indonesia. Honolulu: University of Hawaii Press, 2004.

Geertz, C. The Religion of Java. New York: Free, 1960.

Hatley, R. What's in a name: Arti Sosial seperti Terlihat dalam Nama dan

Perubahan Laziman (Mode) Nama di Jawa. Yogyakarta: Universitas Gadjah Mada Press, 1977.

Hefner, R.W. The Political Economy of Mountain Java: an Interpretive History. Berkeley: University of California Press, 1990.

Hefner, R.W. Islam Pasar Keadilan: Artikulasi Lokal, Kapitalisme, dan Demokrasi. Yogyakarta: LKIS, 2000.

Hoskins, J., "Entering the Bitter House: Spirit Worship and Conversion in West Sumba", in Indonesian Religions in Transition. Tucson: University of Arizona Press, 1987: 136-160.

Hull, T. \& Jones, G., “Demographic Perspectives”, in Indonesia's New Order. Hawai: University of Hawaii Press, 1994.

Hymes, D.H., "On Communicative Competence", in B. Pride and J. 
Holmes (eds.) Sociolinguistics: Selected Readings. London: Penguin Books Ltd., 1972: 269-293.

Jones, G. \& Manning, C., "Labour Force and Employment during the 1980s", in Anne Booth (ed.). The Oil Boom and After: Indonesian

Economic Policy and Performance in the Soeharto Era. Oxford: Oxford University Press, 1992: 363-410.

Jones, G.W. Marriage and Divorce in Islamic South-East Asia. New York: Oxford University Press, 1994.

Kementerian Pendidikan dan Kebudayaan RI. Perkembangan Pendidikan

Tinggi Tahun 199/2000 - 2013/2014. Buku 1 ed. Jakarta: Kementerian Pendidikan dan Kebudayaan RI, 2015.

Kim, H.J. Reformist Muslims in a Yogyakarta Village. Canberra: Department of Anthropology Australian National University, 1996.

Kipp, R. Dissociated Identities: Ethnicity, Religion, and Class in an Indonesian Society. Ann Arbor: University of Michigan Press, 1993.

Koentjaraningrat. Kebudayaan Jawa. Jakarta: Balai Pustaka, 1994.

Kokoschka, A., "Islamizing the Market? Advertising, Products, and Consumption in an Islamic Framework in Syria”, in Muslim Societies in the Age of Mass Consumption. Newcastle upon Tyne: Cambridge Scholars, 2009: 225-240

Kraince, R.G., The Role of Islamic Student Activists in Divergent Movements for Reform during Indonesia's Transition from Authoritarian Rule, 1998. 2001. Ohio: Ohio University Press, 2003.

Kuipers, J.C. Language, Identity and Marginality in Indonesia: The Changing Nature of Ritual Speech on the Island of Sumba. Cambridge: Cambridge University Press, 1998.

Lyon, M. Politics and Religious Identity: Genesis of a Javanese-Hindu Movement in Rural Central Java. Berkeley: Department of Anthropology University of California, 1977.

Moordiati, "Saat Orang Jawa Memberi Nama: Studi Nama di Tahun 1950-2000", Patrawidya, Volume 16, Number 3 (September 2015): 381-390.

Oey-Gardiner, M., "Gender Differences in Schooling in Indonesia", Bulletin of Indonesian Economic Studies, Volume 27 (1991): 57-79.

Poensen, C., "Lets over Javaansche Naamgeving en Eigennamen", in 
Mededeelingen Vanwege het Nederlandsche Zendeling Genootschap XIV. Rotterdam: M. WYT \& Zonen. 1870: 123-216.

Pranowo, M. Creating Islamic Tradition in Rural Java. Melbourne Australia: Department of Anthropology and Sociology Monash University, 1991.

Ricklefs, M. Islamisation and Its Opponents in Java: A Political, Social, Cultural and Religious History, C. 1930 to the Present. Honolulu: University of Hawai'i Press, 2012.

Rossler, M., "Islamization and the Reshaping of Identities in Rural South Sulawesi", in Islam in an Era of Nation-States: Politics and Religious Renewal in Muslim Southeast Asia. Honolulu, HI: University of Hawaii Press, 1997: 275-306.

Schwars, A. A Nation in Waiting: Indonesia in the 1990s. Boulder: Westview, 1994.

Spyer, P., "Diversity with a Difference: Adat and the New Order in Aru (Eastern Indonesia)", Cultural Anthropology, Volume 11, Issue 1 (1996): 25-50.

Uhlenbeck, E.M., "Systematic Features of Javanese Personal Names", in Tatjana Soldatjenkova and Emmanuel Waegemans (eds.). For East is East: Liber Amicorum Wojciech Skalmowski. New York: International Linguistics Association, 1971: 321-335. 
